$\begin{array}{r}\text { Volume and Issues Obtainable at Center for Sustainability Research and Consultancy } \\ \text { Journal of Accounting and Finance in Emerging Economies } \\ \text { ISSN: 2519-0318 ISSN (E) 2518-8488 } \\ \text { Volume 3: Issue 2 December 2017 } \\ \text { JSRᄃ } \\ \text { Journal homepage: } \text { www.publishing.globalcsrc.org/jafee } \\ \hline\end{array}$

\title{
Sustainability Reporting by Firms in the Nigerian Economy: Social versus Environmental Disclosure
}

\author{
${ }^{1}$ Alhassan Haladu, ${ }^{2}$ Basariah Bt. Salim \\ ${ }^{1}$ PhD Scholar, Department of Accountancy, Tunku Puteri Intan Safinaz School of Accountancy (TISSA-UUM), \\ College of Business, Universiti Utara, Malaysia, \\ kirikichichi@gmail.com \\ ${ }^{2}$ Lecturer, Department of Accountancy, Department of Accountancy, Tunku Puteri Intan Safinaz School \\ of Accountancy (TISSA-UUM), College of Business, Universiti Utara, Malaysia, \\ basa1189@uum.edu.my
}

\begin{tabular}{|c|c|}
\hline ARTICLEDETAILS & ABSTRACT \\
\hline $\begin{array}{l}\text { History } \\
\text { Revised format: Nov } 2017 \\
\text { Available online: Dec } 2017\end{array}$ & $\begin{array}{l}\text { Purpose: There is need for specialization on individual categories of } \\
\text { sustainability information disclosure. An attempt has been made in this } \\
\text { study to make a comparison between the environmental and social } \\
\text { categories of sustainability disclosure. }\end{array}$ \\
\hline $\begin{array}{l}\text { Keywords } \\
\text { Sustainability Reporting, } \\
\text { Social Reporting, } \\
\text { Environmental Reporting }\end{array}$ & $\begin{array}{l}\text { Methodology: Guided by the G4 sustainability reporting guidelines, } \\
\text { environmentally sensitive companies in the Nigerian economy were } \\
\text { analyzed for } 6 \text { years }(2009-2014) \text {. Separate assessments and comparisons } \\
\text { were made between environmental reporting and social reporting on the } \\
\text { impact, influence and significance of their relationships using Stata13SE } \\
\text { analytical tool. }\end{array}$ \\
\hline $\begin{array}{l}\text { JEL Classification: } \\
Q 56, K 32\end{array}$ & $\begin{array}{l}\text { analytical tool. } \\
\text { Findings: The results shows that firms performed better on social reporting } \\
\text { than on environmental reporting in terms of higher sustainability disclosure } \\
\text { rates and significant relationships. } \\
\text { Research Implications: The current trend of reporting sustainability } \\
\text { information disclosure under both social and environmental reporting is } \\
\text { encouraging considering the fact that disclosure on sustainability issues in } \\
\text { Nigeria is voluntary. } \\
\text { Practical Implications:Firms in environmentally sensitive sectors are } \\
\text { disclosing sustainability information than expected. } \\
\text { Originality/Value: The uniqueness in comparing sustainability disclosures } \\
\text { between environmental information and social information. }\end{array}$ \\
\hline
\end{tabular}

(C) 2017 The authors, under a Creative Commons AttributionNonCommercial 4.0

Corresponding author's email address: kirikichichi@gmail.com

Recommended citation:Haladu,A. \& Salim,B., (2017). Sustainability Reporting by Firms in the Nigerian Economy: Social versus Environmental Disclosure. Journal of Accounting and Finance in Emerging Economies, 3(2) 87-112. DOI:https://doi.org/10.26710/jafee.v3i2.96

\section{Introduction}

Sustainability information disclosure otherwise referred to as environmental reporting or social accounting or environmental reporting or corporate social responsibility, is a vital ingredient of corporate governance. With the rigorous and selfish pursuance by corporate bodies of increased wealth and growth, the need for sustainability development has become inevitable. In as much as the present generation 
seeks to exploit the finite resources of the earth, it must be aware of the dangers of compromising the ability of future generations to meet their own needs. The emphasis on corporate governance has therefore, made it possible for experts to come out with governance policies that enhances the ability of the next set of people to meet their needs from exploiting the earth's resources without damaging it forever. In Nigeria, the Nigerian Code of Corporate Governance (2011) released by the Nigerian Securities and Exchange Commission (SEC), emphasized on this in Part D under Sustainability Issues [Paragraph 28.1 and 28.3(a) to (i)]. Paragraph 28.3 specifically states that:

"The Board should report annually on the nature and extent of its social, ethical, safety, health and environmental policies and practices" (2011 SEC Code).

The Code went further to explain that all issues in the environmental reports should be categorized into [Ph. 28.3(a) to Ph. 28.3(i)]:

a. Company's business principles and Codes.

b. Workplace accidents, fatalities and occupational \& safety incidents.

c. Company's policies, plans and strategies for HIV/AIDS and other serious diseases on employees.

d. Options with the most environmental benefits or least environmental damages.

e. The nature and extent of employment and gender equality and policies.

f. Number and diversity of staff training and development.

g. Conditions and opportunities for handicapped and physically disabled individuals.

h. Nature and extent of social investment policies.

i. Disclosure of firm's corruption and other related issues, policies and degree of compliance with policies.

The most widely accepted sustainability disclosure standard is the Global Reporting Initiative (GRI) (Brown, de Jong, \& Lessidrenska, 2007). The latest version of this sustainability standard is the G4 Sustainability Reporting Guidelines (2013). This guideline recognizes disclosure based on the Triple Bottom Line reporting (mega reporting) principle with disclosures on economic, environmental and social issues otherwise referred to as the Triple $\mathrm{P}$ (profit, planet and people). Information disclosure in the standard has been classified into (Initiative, 2013):

1. General Standard Disclosure (GSD)

2. Specific Standard Disclosure (SSD)

The GSD discloses general firm attributes of companies like name, address, objectives, accounting yearend, auditor firm, mission \& vision, strategy, relevance, stakeholders' list, industry type \& membership, ethical policies, code of conduct and agreements. The SSD on the other hand reports on economic, environmental and social issues. Researches on sustainability have concentrated so much on examining sustainability disclosures generally at the expense of specialization on the individual categories or subcategories of sustainability development. It must be emphasize that reporting in accounting has traditionally been associated with economic and financial information. In most developing economies specific disclosures on environmental and social issues is new. Where they have been embarked upon (often voluntarily), studies on disclosures on environmental or social issues is very scanty. The need therefore, to assess the degree, nature, and level of disclosure by firms on environmental reporting and social reporting issues independently.

This write-up therefore, aims at making a comprehensive appraisal of social and environmental information disclosure by firms operating in the Nigerian economy. The concentration on these two categorical issues is a fit that has hardly been embarked up even in developed and advanced economies where sustainability reporting is mandatory. Sustainability or similar annual reports by firms covering economic, environmental and social issues hardly yield specific or specialized results exclusive to either environmental or social issues. This gap that exists in sustainability research is what this paper intends to 
fill. Such investigation could provide detail information on the degree, nature and level of a particular standard disclosure attribute independent of economic or financial issues. For simplicity purpose, the paper has been arranged into five sections. After the general introduction which explains the background problems and objectives of sustainability reporting, the literature review gives a brief assessment of the G4 and relationships with sustainability reporting that has been observed. The third section is on the methodology and research design. The fourth section analyses the data and the main findings, while recommendations were outlined in section five which is the last section.

\section{Review of Relevant Literature}

\subsection{Introduction}

Brown et al., 2007 remarked that the GRI sustainability guidelines is today one of the world's most generally accepted environmental reporting standard. This has put it in contention with environmental management standards like ISO 14001, one time the most recognized environmental management standard. In this review of sustainability reporting literature a general overview of the G4 which is the latest version of GRI was done. This was then followed by an assessment of studies on sustainability information disclosure relationship with the aim of identifying researchable areas that has been overlooked or ignored.

\subsection{G4 Sustainability Reporting Guideline and Standard (GRI, 2013)}

This sustainability information reporting guideline is classified into two major parts: The first Part is the General Standard Disclosure (GSD) and the other Part is the Specific Standard Disclosure (SSD). A look at each group reveals the main items to be disclosed under them.

\subsubsection{General Standard Disclosure (Ph. 237)}

a) Strategy \& Analysis (G4-1 to G4-2)

b) Organizational Profile (G4-3 to G4-16)

c) Identified Material Aspects and Boundaries (G4-17 to G4-23)

d) Stakeholders Engagement (G4-24 to G4-27)

e) Report Profile (G4-28 to G4-33)

f) Governance (G4-34 to G4-55)

g) Ethics and Integrity (G4-56 to G4-58)

\subsubsection{Specific Standard Disclosures (SSD)}

This constitutes four major parts:

1. Material Aspects: - Lists identified material aspects.

2. Disclosure on Management Approach (DMA) and Indicators: - Lists specific standard disclosures related to each identified material aspect.

3. Omissions: - In exceptional cases, if it is not possible to disclose certain required information, provision should be made for any omission.

4. External Assurance: - Indicates if the standard disclosure has been externally assured or audited. If so, include the page reference for the external assurance statement in the reports.

\subsection{Major Categories of G4 Specific Standard Disclosure}

Broadly speaking, there are three major categories under SSD section named, some with sub-categories. These categories include economic aspects, environmental aspects and social aspects.

\subsubsection{Economic Category}

"The economic dimension of sustainability concerns the organization's impacts on the economic conditions of its stakeholders, and on economic systems at local, national, and global levels. The Economic Category illustrates the flow of capital among different stakeholders, and the main economic 
impacts of the organization throughout society" (Initial, 2013). In general, disclosures under this category should cover areas of:

1. Economic Performance

2. Market Presence

3. Indirect Economic Impacts

4. Procurement Practices

\subsubsection{Environmental Category}

"The environmental dimension of sustainability concerns the organization's impact on living and nonliving natural systems including land, air, water and ecosystem" (Initiative, 2013). Issues covered under the environmental aspect include impacts related to energy consumed, water used, gas emissions, and effluents \& wastes discharged. Furthermore, aspects like biodiversity, transportation, and product \& service-related impact together with compliance and expenditure of environmental nature are all expected to be disclosed under this category. Major aspects expected to be reported or disclosed are:

1. Materials

2. Energy

3. Water

4. Biodiversity

5. Emissions

6. Effluents and Waste

7. Products and Services

8. Compliance

9. Transport

10. Overall environmental protection and investments

11. Supplier Environmental Assessment

12. Environmental Grievance Mechanisms

\subsubsection{Social Category}

The social dimension of sustainability targets the effects that business organizations have on social systems within which they operate (Initiative, 2013). The sub-categories under the social category are:
a. Labour practices and decent work
b. Human rights
c. Society
d. Product responsibility

\subsubsection{Labour Practice \& Decent Work (Sub-category)}

1. Employment

2. Labour-Management Relationships

3. Occupational Health and Safety

4. Training and Education

5. Diversity and Equal Opportunity

6. Equal Remuneration for Women and Men

7. Supplier Assessment for Labour Practices

8. Labour Practices Grievance Mechanisms

\subsubsection{Human rights (Sub-category)}

1. Investment

2. Non-discrimination

3. Freedom of Association and Collective Bargaining 

4. Child Labour
5. Forced or Compulsory Labour
6. Security Practices
7. Indigenous Rights
8. Assessment
9. Supplier Human Rights Assessment
10. Human Rights Grievance Mechanisms

\subsubsection{Society (Sub-category)}

1. Local Communities

2. Anti-corruption

3. Public Policy

4. Anti-competitive Behaviour

5. Compliance

6. Supplier Assessment for Impacts on Society

7. Grievance Mechanisms for Impacts on Society

\subsubsection{Product Responsibility (Sub-category)}

1. Customer Health and Safety

2. Product and Service Labelling

3. Marketing Communications

4. Customer Privacy

5. Compliance

\subsection{Sustainability Information Disclosure Relationships}

The emphasis of most environmental researches in Nigeria has been on political matters and damages to the environment. Niger Delta inhabitants' agitation against pollution and environmental degradation of their land as it affects their livelihood has been of major concern to all stakeholders in Nigeria. The dependent variable in most of the studies had been environmental reporting while corporate performance has been mostly used as the independent variable (Ahmad, Hassan \& Mohammad, 2003; Akbas, 2014; Andrikopoulos \& Kriklani, 2013; Aquino, 2013; Bhattacharyya, 2014). The measurement of corporate performance has been in terms of firm size, profitability, financial leverage, Market-to-book value, board composition, environmental experts, board size, duality, etc. In other cases, this has been accompanied by testing environmental disclosure relationship with firm age, external audit, industrial membership, effective tax rate, earnings per share, etc. Sustainability reporting on the other hand, is measured either by local Standards/Guidelines/Legislations or international sustainability reporting standards and guidelines like GRI (older versions), ISO 14001, etc. (Adams, 2004).

Results from scholars varied widely with some findings showing that disclosures by most companies were incomplete in the sense that not all items on either the corporate performance or environmental reporting list were disclosed (Adams, 2004; Andrikopoulos \& Kriklani, 2013). In their studies Aquino (2009), Asaolu, Agboola, Ayoola, \& Salamu (2011), Ayoola \& Olasanmi (2013), and Basalamah \& Jermias (2005) discovered that there was no uniformity in environmental reporting by companies. This was mainly due to the use and lack of a globally recognized and endorsed standards or guidelines. In other words, even though businesses come to recognize the need for sustainability disclosures they are yet to reach a consensus on a single guideline or standard.

In noting the basis of comparison provided by corporate disclosures, Ahmad et al., (2003) and Aquino (2009) observed that reports produced by most companies on the environment are positive, favourable to the reporting company and irrelevant. Because of this, there is the need to thoroughly examine the extent 
of disclosure in the nonfinancial sections of company's reports. Accountability in effect is about giving stakeholders information and not about profit alone (Adams, 2004). Stakeholders must be consulted on reports by companies, if not it would be viewed as incomplete and non-mandatory (Adams, 2004; Ahmad et al., 2003). Using a model that compares environmental reporting with corporate performance Adams (2004), concentrated his work on the need to assess the comprehensiveness and extent to which the then current guidelines of GRI and how social and ethical accountability might assist in corporate reporting. Moreover, most of the works done so far on environmental disclosure are cross-sectional and not longitudinal. This cross-sectional view could hardly generalize the trend of a company's environmental performance because results for such investigations could be insufficient or inadequate.

Correlations and regression functions has been used as the major instrument of analysis as studies which seeks to evaluate the relationship between variables. Others have applied simple analytical tools like content analysis, conceptual analysis, and descriptive statistics (Andrikopoulos \& Kriklani, 2013). The problem with content analysis is that it is highly subjective and that scores could be arbitrarily awarded. Ayoola and Olasanmi (2013) for instance, awarded between 0 and 5 points for the different levels of disclosure, while there were no marks for audited and un-audited reports. Other studies like Uwuigbe (2012) used dummy scales for disclosure and non-disclosure ( 0 and 1). This point out the lack of uniformity in measuring the variables used for researches on environmental reporting.

In addition to this, findings from some studies showed inverse relationship between corporate performance and environmental reporting (Ahmad et al., 2003; Connors \& Gao, 2011). In other words, corporate bodies that performed economically well disclose very little on sustainability issues, vice-versa. It is also argued in some researches that firms that disclose more did so in order to justify their poor performance or to give a positive image about their companies (Alabi \& Ntukekpo, 2012; Alfred, 2013; Allen, 2012; Ball, Owen \& Gray, 2000). For instance, higher pollution firms disclose more than lower pollution firms in order to sell to the public the impression of their commitment to fighting pollution (Clarkson \& Overell, 2011). However, direct relationship between corporate performance and environmental reporting was the result of studies by Akbas (2014), Asuquo (2012), Beets and Souther (1999), Cortez (2011) and Tilt and Symes (2000). Thus depicting that companies disclose more on environmental reporting when their economic performance is good and less when their performance is poor.

There are also studies that showed higher levels of compliance with standards on environmental reporting (Alrazi, Sulaiman \& Ahmad, 2009; Anderson, 2003). Lower level compliance with standard was however, reported in the works of Adams and Frost (2006), Bhattacharyya (2014), Carol and Frost (2006), Chown (2000) and Elijido-Ten (2009). This was mainly due to the fact that environmental reporting was regarded as mandatory rather than voluntary. Of much interest however, are the results that showed insignificant or no significant relationship between corporate performance and environmental reporting. Ayoola and Olasanmi (2013), discovered that apart from the lack of uniformity of disclosure by companies, there were no relationships whatsoever between the two variables. The implication was that corporate performance does not in any way influence environmental disclosure. This was buttress by the study of Cormier, Gordon, and Magnan (2004) who concluded that it is management's perception and not corporate performance that determines what is to be disclosed. Whether or not GSD or SSD items on the checklist should be the one to be used, is a question for developing economies to answer. This is buttress by the fact that developing economies have unique environmental issues, as GHGs (Greenhouse gases) are not major environmental problems. In addition, the fact that every economy is unique calls for the use of specific items. However, if proper comparisons are to be made between different economies, then general items are preferable. For the oil and gas industry, GRI emphasizes standard disclosure (G3.1, 2012); and the latest updated GRI guideline (G4) recommends both GSD and SSD disclosures of 
environmental information.

Finally, environmental reporting needs investigation using a broad spectrum of independent variables like policy enforcers, corporate financial performance, board characteristics, operational location, interindustrial comparison, and corporate ownership concentration. For instance, it could make a good research to study the trend of sustainability reporting of environmentally sensitive industries of underdeveloped economies. The same could be done for studies between the natural resources sector and the oil and gas sector, or petroleum mining companies and other non-petroleum mining companies. Significantly, however, there has hardly been any attempt to make a direct comparative analysis of sustainability disclosure among the three aspects of economic, environmental and social emphasized upon by TBL reporting. It will therefore, serves as a pioneer undertaking to make a comparative examination of the relationship between environmental reporting and specific corporate characteristics on the one hand; and social reporting and specific corporate characteristics on the other.

\subsection{Summary}

In summary, it is clear that past studies have not attempted to cover specific categories of sustainability reporting. The study of Enahoro (2009) which is one of the studies that specializes on sustainability covered only the oil \& gas and industrial goods sectors. There is also the question of mixed results in terms of significant, direct, or indirect relationships between variables. The emphasis on just one or few components of variables (corporate performance, website, etc.) is also an area of concern. Past studies have been wholly dominated by the use of annual financial reports as opposed to sustainability reports. Above all the most globally acceptable standard GRI has now been upgraded to G4. There is yet to be a study conducted on developing economies in particular; using its provisions. While emphasis has been laid on and targeted sustainability reporting, there is the need to separate the two distinctive aspects of sustainability reporting: social reporting and environmental reporting. It is worth noting that the beneficiaries of environmental pollution in Nigeria are not the victims. This is particularly true in the Niger Delta area where the local inhabitants are most highly subjected to wastes, emissions and effluents from the processing of petroleum products that needs both environmental and social disclosures.

\section{$3 \quad$ Methodology}

\subsection{Introduction}

Like most developing and African economies, the Nigerian economy is dominated by small and mediumscale enterprises (SMEs). However, in the formal sector though lots of business organizations are registered with the Corporate Affairs Commission (CAC), not all of them are listed in the Nigerian Stock Exchange (NSE). Firms operating and/or quoted in the NSE could be grouped into two broad categories for sustainability purposes: non-environmentally sensitive and environmentally sensitive sectors. The non-environmentally sensitive sector consists of financial and nonfinancial industries. In the financial section, three industries containing 88 companies are registered, while in the nonfinancial section four industries with some 64 companies are quoted (NSE Factbook, 2012/2013). The environmentally sensitive sector consists of six industries and 81 firms (Table 3.1).

Table 3.1: Major Sectors in the Nigerian Economy (Population of the Study)

\begin{tabular}{lr}
\hline Sectors & No. of Quoted Firms \\
\hline Agriculture & 5 \\
Construction/Real Estate & 10 \\
Healthcare & 10 \\
Industrial Goods & 28 \\
Natural Resources & 6 \\
Oil \& Gas & 22 \\
\hline Sub-Total & $\mathbf{8 1}$ \\
\hline
\end{tabular}

Source: Website and NSE FactBook 2011/12 \& 2012/13 


\subsection{Research Design}

This study is designed in a way that states the population, sample size, variables used for the research, framework and model, and then the tools of analysis used. The population of the study does not consider all firms in the 13 sectors of the NSE. It is defined in terms of the six sectors that make up the environmentally sensitive sector. Contained in this sector are a total of 81 firms in the agriculture, construction/real estate, healthcare, industrial goods, natural resources and oil \& gas sectors. This therefore, gives the population of the research a total of 81 firms in all the six sectors covered (Table 3.1). The sample size was determine through the application of Collins \& Schultz formulae as applied by Kantudu (2006), Enahoro (2009) and Nyor (2008) to give a sample size of 67 companies each of which covered the period 2009 to 2014. The variables evaluated were sustainability reporting (dependent variable) and environmental policy administrators, corporate financial performance, board characteristics, corporate ownership concentration and specific corporate characteristics (independent variables). Sustainability reporting constituted two categories: social reporting and environmental reporting. These were measured through content analysis (dummies) using the GRI4 (G4) sustainability (environmental and social) disclosure standards (Table 3.2).

Table 3.2: Classification and Measurement of Variables

\begin{tabular}{|c|c|c|c|}
\hline Classification & Variables & Measurement & Author/Source \\
\hline \multicolumn{4}{|c|}{ Dependent Variables } \\
\hline Sustainability & Social Disclosure & Content Analysis $(0,1)$ & Ahmad, \\
\hline Disclosure & $\begin{array}{l}\text { Environmental } \\
\text { Disclosure }\end{array}$ & Content Analysis $(0,1)$ & $\begin{array}{l}\text { Mohammad (2003), Sulaiman } \\
\& \quad \text { Mokhtar } \quad(2012) \text { and } \\
\text { Monteiro \& Aibar-Guzman } \\
(2010)\end{array}$ \\
\hline \multicolumn{4}{|c|}{ Independent Variables } \\
\hline $\begin{array}{l}\text { Environmental Policy } \\
\text { Administrators }\end{array}$ & $\begin{array}{l}\text { Nigerian } \\
\text { Exchange (NSE) } \\
\text { DPR/NESREA } \\
\text { Ministry of Environment } \\
\text { (MOE) }\end{array}$ & $\begin{array}{l}\text { Mean Value Index } \\
\text { (MVI) }\end{array}$ & $\begin{array}{l}\text { Hossain, Islam, \& } \text { Andrew, } \\
\text { 2006; Enahoro, } 2009 \text {; } \\
\text { Sulaiman and Mokhtar, } 2012\end{array}$ \\
\hline \multirow{4}{*}{$\begin{array}{l}\text { Corporate } \\
\text { Financial/Economic } \\
\text { Performance }\end{array}$} & Profitability & NPAT/Total Equity * & Ahmad, Hassan \\
\hline & Firm Size & Log of Total Assets & $\begin{array}{l}\text { Monteiro \& Aibar-Guzman, } \\
2010\end{array}$ \\
\hline & Financial Leverage & Debt/Equity * 100 & $\begin{array}{l}\text { Andrikopoulos \& Kriklani, } \\
2013\end{array}$ \\
\hline & $\begin{array}{l}\text { Market-to-Book Value } \\
(\mathrm{MBV}) \text { Ratio }\end{array}$ & MBV Ratio & $\begin{array}{l}\text { Andrikopoulos \& Kriklani, } \\
2013\end{array}$ \\
\hline \multirow[t]{4}{*}{ Board Characteristics } & Board Composition & $\begin{array}{l}\text { Non-executive/Executive } \\
\text { Ratio }\end{array}$ & $\begin{array}{l}\text { Eng and Mak, 2003; Barako, } \\
\text { Hancock and Izan, } 2006\end{array}$ \\
\hline & CEO's Dual Role & Content Analysis $(0,1)$ & $\begin{array}{l}\text { Barako, Hancock and Izan, } \\
2006\end{array}$ \\
\hline & Environmental Expert & Content Analysis $(0,1)$ & Sulaiman \& Mokhtar, 2012 \\
\hline & Board Size & $\begin{array}{l}\text { Total Number of Board } \\
\text { Members }\end{array}$ & Cheng \& Courtenay, 2006 \\
\hline $\begin{array}{l}\text { Corporate Ownership } \\
\text { Concentration }\end{array}$ & $\begin{array}{l}\text { Corporate ownership } \\
\text { concentration }\end{array}$ & $\begin{array}{l}\text { Foreign \& Indigenous }(0, \\
\text { 1) }\end{array}$ & $\begin{array}{l}\text { Al-Farooque, 2010; Delgado- } \\
\text { Garcia, Quevedo-Puente, \& } \\
\text { Fuente-Sabate, 2010; Fauzi, \& } \\
\text { Locke, 2012; and Maquieira, } \\
\text { Espinosa \& Vieito, } 2012 \\
\text { (Percentage). } \\
\text { Monteiro \& Aibar-Guzman, } \\
2010 ; \quad \text { Prado-Lorenzo, }\end{array}$ \\
\hline
\end{tabular}


Gallego-Alvarez, and GarciaSanchez, 2009 (Dummy).

\begin{tabular}{|c|c|c|c|}
\hline $\begin{array}{l}\text { Other Specific } \\
\text { Corporate }\end{array}$ & Firm Age & $\begin{array}{l}\text { Firm Age since } \\
\text { incorporation }\end{array}$ & Elijido-Ten, 2009 \\
\hline \multirow[t]{3}{*}{ Characteristics } & Audit Firm & $\operatorname{Big}$ Four $(0,1)$ & $\begin{array}{l}\text { Ballou, Heitger, \& Landes } \\
2006\end{array}$ \\
\hline & Effective Tax Rate & Tax Payable/PBIT $* 100$ & $\begin{array}{l}\text { Smith, Amiruddin, \& Yahya, } \\
2007\end{array}$ \\
\hline & Industrial Type & $\begin{array}{l}\text { Lowly \& Highly } \\
\text { Sensitive }(0,1)\end{array}$ & $\begin{array}{l}\text { Ahmed, Hassan \& Junaini, } \\
\text { 2003; Akbas, 2014; Ismail \& } \\
\text { Ibrahim, 2009; Smith, } \\
\text { Amiruddin, \& Yahya, } 2007\end{array}$ \\
\hline
\end{tabular}

Source: Computed from literature reviewed

Measurements of the 16 elements that constituted the independent variables are also given in Table 3.2. Environmental policy administrators was measured by a Mean Value Index (MVI). This index was obtained through a draft questionnaire that constituted nine items aimed at showing the level of compliance with sustainability disclosure standards by sectors under environmental monitoring agencies of either NSE, DPR, NESREA or MOE. The items were scored 0 to 5 with zero representing noncompliance and $1-5$ denoting the level of compliance from very weak to very strong. The average score was then computed and expressed as a ratio to form the MVI (Appendix III). Based on the preferred KMO and Cronbach's Alpha, it was agreed that the scale variable instrument applied for the MVI on the research was within acceptable range as shown on Table 3.3 (Min, 2010; Tsafe, 2013).

Table 3.3:Validity and Reliability Tests of MVI

\begin{tabular}{lrr}
\hline Variable & $\begin{array}{c}\text { KMO value } \\
\text { (Validity) }\end{array}$ & $\begin{array}{c}\text { Alpha value } \\
\text { (Reliability) }\end{array}$ \\
\hline $\begin{array}{l}\text { Nigerian Stock Exchange \& Ministry of Environment } \\
\text { Department of Petroleum Resources \& National }\end{array}$ & $93.2 \%$ & $63.7 \%$ \\
$\begin{array}{l}\text { Environmental Standards and Regulations Enforcement } \\
\text { Agency }\end{array}$ & $69.6 \%$ & $74.2 \%$ \\
\hline
\end{tabular}

Similarly, normality test on the dataset in the distribution shows that there were no problems of abnormality as results on Table 3.4 gives Skewness of less than 2 and Kurtosis of less than 10 for all the variables applied for this research.

Table 3.4:Test for Normality of Data

\begin{tabular}{lrr}
\hline Variables & Skewness $(\leq \pm \mathbf{2})$ & Kurtosis $(\leq \mathbf{1 0})$ \\
\hline Social disclosure & 0.0435 & 2.3121 \\
Environmental disclosure & 0.1282 & 2.8324 \\
Simple average disclosure index & 0.3104 & 2.0205 \\
Environmental policy administrators & 0.7865 & 3.0040 \\
Corporate performance & 1.7729 & 7.0339 \\
Board characteristics & 0.5308 & 3.7151 \\
Other corporate characteristics & 0.6720 & 3.2618 \\
$\boldsymbol{A V E R A G E}$ & $\mathbf{0 . 6 0 6 3}$ & $\mathbf{3 . 4 5 4 3}$ \\
\hline
\end{tabular}

\subsection{Research Framework and Model}

The frameworks of the study which are based on both the institutional theory and political economy theory are given below. 


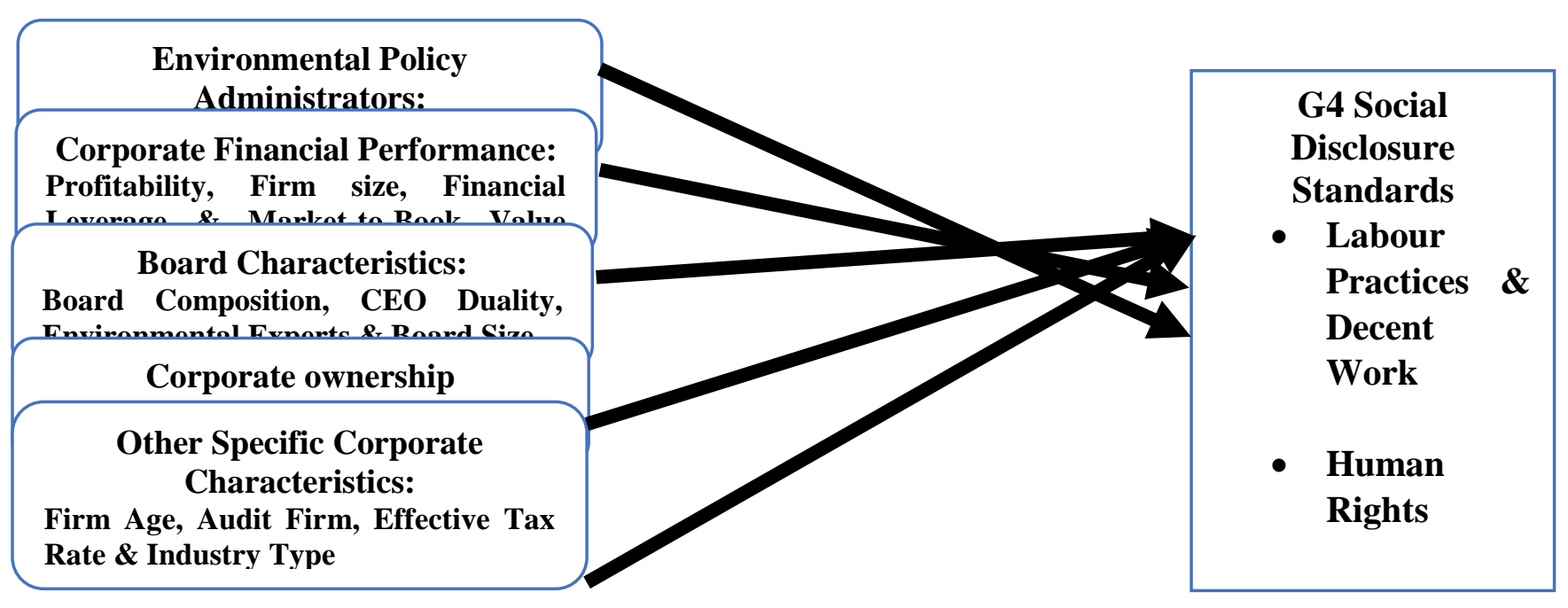

Figure 3.1: Social Sustainability Disclosure Framework

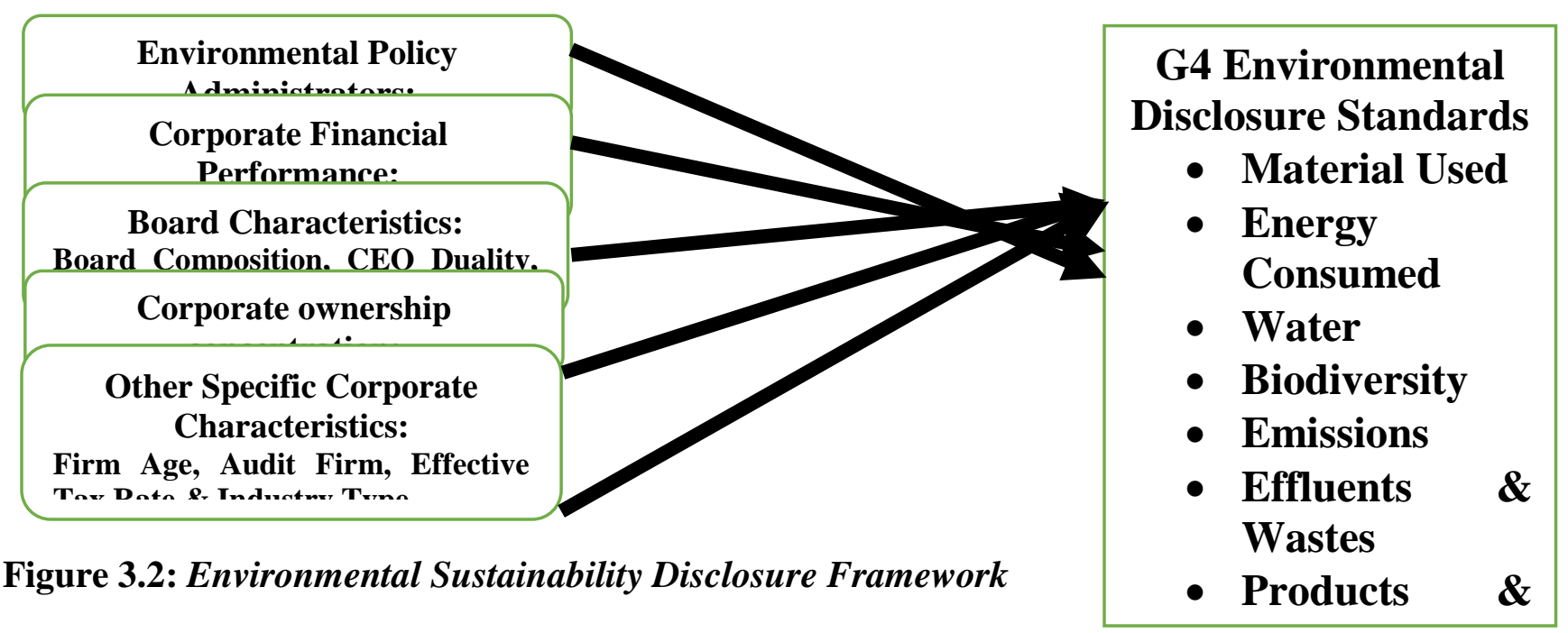

These frameworks are represented in two sustainability models:

(i) Social reporting model

(ii) Environmental reporting model

Where:

$$
\begin{array}{llll}
S R_{i t} & =a_{0}+\beta_{1} E P A_{i t}+\beta_{2} C F P_{i t}+\beta_{3} B O C_{i t}+\beta_{4} C O S_{i t}+\beta_{5} S C C_{i t}+\varepsilon & \text { (i) } \\
E R_{i t} & =a_{0}+\beta_{1} E P A_{i t}+\beta_{2} C F P_{i t}+\beta_{3} B O C_{i t}+\beta_{4} C O S_{i t}+\beta_{5} S C C_{i t}+\varepsilon & \text { (ii) }
\end{array}
$$

$\mathrm{SR}_{\mathrm{it}} \quad=$ social sustainability reporting

$\mathrm{ER}_{\mathrm{it}}=$ environmental sustainability reporting

$\mathrm{a}_{0} \quad=$ constant term

$\varepsilon=$ error at $5 \%$ level of significance

$\beta_{0-n}=$ coefficient of the independent variables

EPA = environmental policy administrators

$\mathrm{CFP}=$ corporate financial performance

BOC = board characteristics

COS = corporate ownership concentration 
$\mathrm{SCC}=$ specific corporate characteristics

These models [(i) and (ii)] would be used to test for the assertions that:

$\mathrm{H}_{01}$ there are no significant relationship between social reporting and sustainability disclosure determinants

$\mathrm{H}_{02}$ there are no significant relationship between environmental reporting and sustainability disclosure determinants

The data was analysed using Stata13SE tool of analyses as it is seen as the best analytical tool for panel observations. The analysis mainly targeted the type and significance of relationships, the impacts on sustainability disclosure and the overall significance of the predictor variables (f-value); such that comprehensive comparison could be conducted.

\section{Discussion and Results}

\subsection{Introduction}

The variables that make up the research of the study were analysed and discussed in detail in this section. The discussions were guided by the objectives and hypothetical assertions of the study. To achieve this, this section has been organized in such a way that general descriptions of the nature, level and pattern of disclosure were done first. The arrangement looked at social sustainability disclosure, which was then followed by environmental disclosure and finally the independent variables. The aim is to assess the level of disclosure of each elements of the variables together with the distribution of information in the dataset. An analysis of the correlation was done to pinpoint the existence of any relationship between sustainability reporting and its determinants, and the issue of collinearity or multi-correlation. The final evaluation was on determining the impact, direction and significance of the relationship of both social and environmental sustainability reporting with the sustainability determinants. From these analysis the implications were then determine.

\subsection{Descriptive Statistics}

Table 4.1 is the result of the descriptive statistics on the elements of social sustainability disclosure. Average disclosure rate for health \& safety, privileges and social policy as well as employment were about $60 \%$. The remaining four elements however, have disclosure rates of below $32 \%$.

\section{Table 4.1: Descriptive Statistics of Social Sustainability Disclosures}

\begin{tabular}{lrrrr}
\hline Variable & Mean & $\begin{array}{r}\text { Standard } \\
\text { Deviation }\end{array}$ & Minimum & Maximum \\
\hline Health \& Safety & 0.7532 & 0.4317 & 0 & 1 \\
Training \& Education & 0.2905 & 0.4546 & 0 & 1 \\
Equal Rights & 0.3085 & 0.4625 & 0 & 1 \\
Privileges & 0.7069 & 0.4558 & 0 & 1 \\
Social Policy & 0.8612 & 0.3462 & 0 & 1 \\
Organizational Responsibility & 0.2699 & 0.4445 & 0 & 1 \\
Employment & 0.5964 & 0.4913 & 0 & 1 \\
Relationship with Community & 0.2237 & 0.4172 & 0 & 1 \\
\hline Sadi (Social Sustainability Disclosure) & $\mathbf{0 . 5 0 1 3}$ & $\mathbf{0 . 3 2 0 8}$ & $\mathbf{0}$ & $\mathbf{1}$ \\
\hline
\end{tabular}

Of the eight elements that constituted social disclosure $50 \%$ of them, have very good disclosure rates of about $60 \%$, while training \& education, equal rights, organization responsibility and community relationship shows disclosures of around 30\%. This result is very poor especially when it is considered that one of the most important social disclosure elements (relationship with community) scored just $22.37 \%$. Though the average social disclosure rate is $50.13 \%$ the fact that an important issue like community relationship was poorly disclosed tells a lot on the images of firms in the industry. Distribution in the data was fairly even as indicated by the standard deviation which have all its values below one. Minimum and maximum disclosures were 0 and $100 \%$ respectively. 
For elements that constituted environmental disclosures, the results on Table 4.2 shows that only materials used and energy consumed have disclosure rates of over $60 \%$. Elements like effluents, biodiversity \& wastes, product's environmental impact and EMD (environmental management department), all scored below 35\% disclosure rate. The implication is that disclosure of output production materials was very poor. In fact, the most critical environmental elements of biodiversity \& wastes scored only $21.85 \%$ disclosure rate. This is an indication that firms' treatment of disclosure on environmental sustainability is not encouraging at all. It could equally be argued that the high rate of disclosure on material and energy was as a result of these costs items being directly incurred by firms; otherwise, the disclosure rate would not have been that good.

Table 4.2: Descriptive Statistics of Environmental Sustainability Disclosures

\begin{tabular}{lrrrr}
\hline Variable & Mean & $\begin{array}{r}\text { Standard } \\
\text { Deviation }\end{array}$ & Minimum & Maximum \\
\hline Material Used & 0.8689 & 0.3380 & 0 & 1 \\
Energy Consumed & 0.6427 & 0.4798 & 0 & 1 \\
Effluents & 0.2442 & 0.4302 & 0 & 1 \\
Biodiversity \& Wastes & 0.2185 & 0.4138 & 0 & 1 \\
Environmental Impact of the Product & 0.3059 & 0.4614 & 0 & 1 \\
Environmental Management Department & 0.3008 & 0.4592 & 0 & 1 \\
\hline Sadi (Environmental Sustainability Disclosure) & $\mathbf{0 . 4 3 0 2}$ & $\mathbf{0 . 3 2 4 5}$ & $\mathbf{0}$ & $\mathbf{1}$ \\
\hline
\end{tabular}

In the face of this, a relatively poor average environmental disclosure was made (43.02\%). Notwithstanding, the data distribution shows even distribution as all of the standard deviation results were below one. Just as with social disclosure, the environmental disclosure recorded minimum and maximum scores of 0 and $100 \%$ respectively. The elements of the independent variables on Table 4.3 could be classified into five groups thus:

1. Environmental policy administrators: - NSE, DPR, NESREA and Ministry of Environment (MOE).

2. Corporate financial performance: - profitability, firm size, financial leverage and market-to-book value $(\mathrm{MBV})$ ratio.

3. Board characteristics: - board composition, duality, environmental experts and board size.

4. Corporate ownership concentration: - foreign ownership and indigenous ownership.

5. Other specific corporate characteristics: - firm age, audit firm, effective tax rate, and industry type.

Results for the 16 independent variables shows mixed disclosure rates (Table 4.3). For environmental policy administrators the elements shows mean disclosures of $60.93 \%, 49.42 \%$ and $74.46 \%$ for NSE, DPR/NESREA and MOE, and their standard deviations given as 0.0206, 0.0957 and 0.0591 respectively. The standard deviation shows that the data spread within the observations are even. The minimum and maximum level falls between $38.32 \%$ (DPR/NESREA) and 66.98\% (MOE). The disclosure for environmental policy administrators depicts a good result as average disclosure show a result of approximately $61.67 \%$. A level high enough to qualify the monitoring agencies' as effective and efficient environmental supervisory bodies. 
Table 4.3: Descriptive Statistics of Predictor Variable Disclosures

\begin{tabular}{lrrrr}
\hline Independent Variables & Mean & $\begin{array}{c}\text { Standard } \\
\text { Deviation }\end{array}$ & Minimum & Maximum \\
\hline Nigerian Stock Exchange (NSE) & 0.6093 & 0.0206 & 0.5818 & 0.6545 \\
DPR/NESREA & 0.4942 & 0.0957 & 0.3832 & 0.6664 \\
Ministry of Environment (MOE) & 0.7446 & 0.0591 & 0.6698 & 0.6664 \\
Profitability & 2.0533 & 5.3244 & -6.0333 & 22.4294 \\
Firm Size & 6.6550 & 0.8081 & 4.7997 & 9.4982 \\
Financial Leverage & 3.6241 & 6.4954 & 0 & 28.5811 \\
Market-to-Book Value (MBV) Ratio & 3.4190 & 5.3294 & -3.5714 & 22.7273 \\
Board Composition & 1.6482 & 1.0362 & 0 & 4.5000 \\
Duality & 0.7172 & 0.4509 & 0 & 1 \\
Environmental Expert & 0.1388 & 0.3462 & 0 & 1 \\
Board Size & 9.2596 & 2.4823 & 2 & 18 \\
Corporate Ownership & 0.4139 & 0.4932 & 0 & 1 \\
Firm Age & 40.8226 & 24.4472 & 7 & 130 \\
Audit Firm & 0.2494 & 0.4332 & 0 & 1 \\
Effective Tax Rate & 26.2812 & 16.9589 & -3.0200 & 79.9100 \\
Industrial Type & 0.6015 & 0.4902 & 0 & 1 \\
Average Disclosure Rates: & & & & 0.6167 \\
Environmental policy administrators & & & & 3.9379 \\
Corporate performance & & & & \\
Board characteristics & & & & 0.4139 \\
Corporate ownership concentration & & & & 16.9887 \\
Other specific corporate characteristics & & & & \\
\hline
\end{tabular}

With corporate performance, profitability which is measured in percentage terms shows that average profit disclosed is about $205.33 \%$ of equity. The minimum profit disclosed was a loss of $603.33 \%$ and the maximum profit disclosure of 2,242.94\% of equity. The profit accrued was however, not evenly distributed during the six-year period observed as standard deviation shows a result of 5.3244. The range of profit was very wide as the difference between the highest profit and losses recorded was 2,846.27\%. A difference that could be attributed mainly to the large number of oil \& gas firms in the observation compared to very small industries. This notwithstanding, average returns on investments is very encouraging at $205.33 \%$ of equity. Firm size shows a record of 6.6550 on average. The standard deviation of 0.8081 indicates the even pattern of data distribution in the observation. Minimum asset base shows 4.7997 with maximum asset base showing 9.4982. Financial leverage was about three times the average investment (362.41\%). With minimum and maximum values of 0 and $2,858.11 \%$ on respectively, it shows from the standard deviation that distribution in the data set was not even. This shows that high dependence on debt financing could be unreliable as creditors may recall their capital in cases of financial insecurity. Market-to-book value (MBV) ratio was also very high and stood on average at $341.90 \%$ of equity, with minimum and maximum disclosure of $-357.14 \%$ and $2,272.73 \%$ respectively. The standard deviation was however, poor at 5.3294. On average corporate performance was disclosed at $393.79 \%$.

For elements of the board characteristics variables, board composition on average is 1.6482 non-executive members to each executive member. This shows that non-executive members outnumbered executive members in the Board of Directors (BOD) by a ratio of about 1.5 to 1 making the boards to be independent. There are some firms however, that have zero non-executive members in their BOD while the highest number of non-executive members to executive members was 4.5 to 1 . $71.72 \%$ of Chief Executive Officers (CEO) are holding single positions as board members. This supports the provision of the code of corporate governance (2011) Part B Sec 5.1(b) (2011 SEC Code) which, frowns on BOD members holding more than one position which could lead to clash of interest. Environmental experts are in only $13.88 \%$ of firms. This is an indication of the lack of seriousness that is given to environmental issues by firms in the economy. Distribution of data for both CEO's duality and environmental expert is 
uniform. Board size shows average membership of about nine members. The code of code of corporate governance (2011) recognizes at least five members in a company's board according to Part B Sec 4.2 (2011 SEC Code). The minimum and maximum membership recorded were 2 and 18 members respectively. The most important outcome of board characteristics is that except for environmental experts and board size, none of the provisions of the code of corporate governance was violated by any of the firms studied with regards to board composition and CEO's dual role. It was however, discovered that not all firms have environmental experts in their boards and at least 5 members in the BOD. Board characteristics showed an average disclosure of $294.10 \%$.

In terms of corporate ownership concentration, it is clear that the results shows a $41.39 \%$ foreign ownership. This is an indication of the low rate of foreign investments in the country. A situation not encouraging for sustainability. Foreign firms especially from western developed economies are more experienced with environmental reporting issues and the fact that environmental reporting is mandatory in their home would force them to apply it to all their divisions or foreign branches. The low rate of foreign corporate ownership could undermine sustainability reporting. Alternatively, local ownership outweighs foreign ownership and stood at an estimated $58.61 \%$.

A look at some specific firm characteristics shows that average firm age is given as around 41 years with firms as young as seven years while the oldest firm recorded since incorporation was 130 years. This shows that the companies observed for the study are highly experienced. 40 years of operation as a business entity commands a lot of experience as such firms are expected to be more efficient and effective in relaying their sustainability records. Audit firm record shows that only $24.94 \%$ of firms in environmentally sensitive sectors are audited by the Big Four accounting firms. With a standard deviation below one, it means the distribution is even. Effective tax rate show a figure of 26.28\%. This figure is below the official tax rate in Nigeria which is $30 \%$. It means effectively that companies are paying at a rate which is below the official tax rate. Industrial type result shows that about $60.15 \%$ of firms observed are highly sensitive while the remaining $39.85 \%$ are lowly sensitive firms. This is an indication of the possibility of a high pollution rate by firms. Average disclosure by specific firm characteristics stood at $1,698.87 \%$.

\subsection{Correlation Matrix Index}

An assessment of the correlation matrix shows that a relationship exists between social and environmental reporting and all predictors as none of the indices shows a 100\% relationship. Appendix I shows that about $56 \%$ of the relationship between social reporting and its predictors are significant. Additionally, except for the inverse relationship between corporate ownership and industry type (-0.9685), collinearity of variables are completely absent. While all the predictor variables have positive relationships with social disclosure, DPR/NESREA, MOE, MBV ratio, board composition, duality, audit firm and industry type have an inverse relationship with social disclosure. This indicates that the better these variables perform, the lower the social sustainability disclosure.

On the other hand, an evaluation of the correlation matrices for environmental sustainability (Appendix II) shows that both positive and negative relationship exists with the predictors. As in the case of social disclosure $43.75 \%$ of the independent variables constituting DPR/NESREA, MOE, MBV ratio, board composition, duality, audit firm and industry type; have negative relationship with environmental disclosure. Likewise, collinearity only exists between corporate ownership concentration and industrial type (-0.9685). In terms of significance, $62.50 \%$ of the relationships are significant in their relationships with environmental reporting. 


\subsection{Regression Analysis}

The regression result gives similar and mixed outcome as shown on Table 4.4 and Table 4.5. The major similarities are in terms of relationship types. Except for firm age which shows direct relationship with social disclosure and inverse relationship with environmental disclosure, all other relationships between the two disclosure-types are similar in the sense that they are of the same type (move in the same direction). Furthermore, the NSE is the only predictor variable with an impact of over $100 \%$, even though the same result under environmental disclosure is higher. All other predictors under social and environmental disclosure affected disclosure by less than $100 \%$. The major differences lie in the significance of the impact. Results for social sustainability disclosure show that $56.25 \%$ of the impacts are significant while for environmental sustainability disclosure, only $43.75 \%$ of variables are significant.

Table 4.4: Regression Analysis for Social Sustainability Disclosure

\begin{tabular}{|c|c|c|c|}
\hline $\begin{array}{l}\text { F-value } \\
\mathrm{R}^{2}\end{array}$ & & & $\begin{array}{r}0.0000 \\
0.1803 \\
\end{array}$ \\
\hline Sadi & Coefficient & t-value & p-value \\
\hline NSE & 1.7165 & 2.3200 & 0.0210 \\
\hline DPR/NESREA & -0.5590 & -3.4600 & 0.0010 \\
\hline Ministry of Environment & -0.0706 & -0.2600 & 0.7910 \\
\hline Profitability & 0.0057 & 1.5500 & 0.1230 \\
\hline Firm Size & 0.0530 & 2.1100 & 0.0360 \\
\hline Financial Leverage & 0.0046 & 1.4500 & 0.1480 \\
\hline Market-to-Book Value Ratio & -0.0065 & -2.1500 & 0.0320 \\
\hline Board Composition & -0.0135 & -0.7800 & 0.4330 \\
\hline Duality & -0.0341 & -0.9900 & 0.3230 \\
\hline Environmental Expert & 0.0977 & 1.6800 & 0.0950 \\
\hline Board Size & 0.0085 & 1.1400 & 0.2560 \\
\hline Corporate ownership concentration & -0.1899 & -18300 & 0.0690 \\
\hline Firm Age & -0.0000 & -0.0600 & 0.9550 \\
\hline Audit Firm & -0.0690 & -1.6500 & 0.1000 \\
\hline Effective Tax Rate & 0.0020 & 1.8800 & 0.0610 \\
\hline Industry Type & -0.1819 & -1.7000 & 0.0890 \\
\hline
\end{tabular}

Variables like NSE, firm size, environmental expert, corporate ownership concentration and industry type are significant under both social and environmental sustainability disclosures. Whereas for MOE, financial leverage, and board composition and firm age, the results under both estimates are insignificant. For six of the variables (37.50\%) however, the results are the opposite. These include DPR/NESREA, profitability MBV ratio, CEO duality, audit firm and effective tax rate. The summary on Table 4.6 explains better these findings.

Table 4.5: Regression Analysis for Environmental Sustainability Disclosure

\begin{tabular}{|c|c|c|c|}
\hline $\begin{array}{l}\text { F-value } \\
\mathrm{R}^{2}\end{array}$ & & & $\begin{array}{l}0.0000 \\
0.2022 \\
\end{array}$ \\
\hline Sadi & Coefficient & t-value & p-value \\
\hline NSE & 2.3220 & 3.1700 & 0.0020 \\
\hline DPR/NESREA & -0.4110 & -2.5200 & 0.1200 \\
\hline Ministry of Environment & -0.1057 & 0.3500 & 0.7240 \\
\hline Profitability & 0.0066 & 1.7700 & 0.0770 \\
\hline Firm Size & 0.0631 & 2.4700 & 0.0140 \\
\hline Financial Leverage & 0.0039 & 1.2500 & 0.2110 \\
\hline Market-to-Book Value Ratio & -0.0045 & -1.3900 & 0.1650 \\
\hline Board Composition & -0.0093 & -0.5500 & 0.5820 \\
\hline CEO’s Dual Role & -0.0640 & -1.8600 & 0.0640 \\
\hline Environmental Expert & 0.1306 & 2.3100 & 0.0220 \\
\hline Board Size & 0.0111 & 1.4800 & 0.1400 \\
\hline Firm Age & 0.0002 & 0.2100 & 0.8330 \\
\hline Audit Firm & -0.0446 & -1.0700 & 0.2860 \\
\hline
\end{tabular}




\begin{tabular}{lrrr} 
Effective Tax Rate & 0.0005 & 0.5200 & 0.6040 \\
Corporate ownership concentration & -0.1482 & -2.0300 & 0.0430 \\
Industry Type & -0.1695 & -2.2200 & 0.0270 \\
\hline
\end{tabular}

The comparison between the sustainability disclosures on Table 4.6 shows that while both the minimum and maximum rates of disclosure gives values of 0 and $100 \%$ respectively, average sustainability disclosure shows $50.13 \%$ and $43.02 \%$ for social and environmental sustainability respectively. This implies that social disclosure by firms is higher than environmental disclosures on sustainability issues. The impact of the predictors on social reporting gives an $\mathrm{R}^{2}$ value of $18.03 \%$ for social reporting and $20.22 \%$ for environmental reporting giving environmental disclosure the advantage. The f-statistics showing the total significance of all the independent variables gives very good result for both by showing that they are highly significant at $1 \%$ level of significance. For the sustainability disclosure determinants, there were similar results under both social and environmental reporting for variables like NSE, MOE, firm size, financial leverage, board composition, environmental expert, board size, firm age, corporate ownership and industry type. However, social disclosure has better results with attributes like average sustainability disclosure, DPR/NESREA, MBV ratio, audit firm and effective tax rate. Similarly, environmental sustainability disclosure performs better in terms of attributes like impact $\left(\mathrm{R}^{2}\right)$, profitability and duality. It should therefore, be concluded that while social disclosure performs better in five of the attributes analysed, environmental disclosure performs better in only three of these attributes. The two have equal performance in the remaining 13 attributes.

Table 4.6: Comparison between Social and Environmental Disclosure

\begin{tabular}{|c|c|c|c|}
\hline Indices & Social Disclosure & $\begin{array}{l}\text { Environmental } \\
\text { Disclosure }\end{array}$ & Remarks \\
\hline \multicolumn{4}{|l|}{ Disclosure } \\
\hline Minimum Disclosure & 0.0000 & 0.0000 & EQUAL \\
\hline Maximum Disclosure & 1.0000 & 1.0000 & EQUAL \\
\hline $\mathrm{R}^{2}$ & $18.03 \%$ & $20.22 \%$ & $E>S$ \\
\hline F-statistics & 0.0000 & 0.0000 & EQUAL \\
\hline Predictor Variables & & t \& p values & \\
\hline \multicolumn{4}{|c|}{ l Policy Administrators } \\
\hline NSE & Positive \& Significant & Positive \& Significant & Equal \\
\hline DPR/NESREA & Negative \& Significant & Negative \& Insignificant & S Better than E \\
\hline Ministry of Environment & Negative \& Insignificant & Positive \& Insignificant & Equal \\
\hline \multicolumn{4}{|c|}{ Corporate Economic Performance } \\
\hline Profitability & Positive \& Insignificant & Positive \& Significant & E Better than $S$ \\
\hline Firm Size & Positive \& Significant & Positive \& Significant & Equal \\
\hline Financial Leverage & Positive \& Insignificant & Positive \& Insignificant & Equal \\
\hline $\begin{array}{l}\text { Market-to-Book Value } \\
\text { Ratio }\end{array}$ & Negative \& Significant & Negative \& Insignificant & S Better than $\mathrm{E}$ \\
\hline \multicolumn{4}{|c|}{ Board Characteristics } \\
\hline Board Composition & Negative \& Insignificant & Negative \& Insignificant & Equal \\
\hline Duality & Negative \& Insignificant & Negative \& Significant & E Better than $S$ \\
\hline Environmental Expert & Positive \& Significant & Positive \& Significant & Equal \\
\hline Board Size & Positive \& Insignificant & Positive \& Insignificant & Equal \\
\hline \multicolumn{4}{|c|}{ Corporate Ownership Concentration } \\
\hline $\begin{array}{l}\text { Corporate } \quad \text { Ownership } \\
\text { (Foreign) }\end{array}$ & Negative \& Significant & Negative \& Significant & Equal \\
\hline \multicolumn{4}{|c|}{ Other Specific Corporate Characteristics } \\
\hline Firm Age & Negative \& Insignificant & Positive \& Insignificant & Equal \\
\hline Audit Firm & Negative \& Significant & Negative \& Insignificant & S Better than $\mathrm{E}$ \\
\hline Effective Tax Rate & Positive \& Significant & Positive \& Insignificant & S Better than E \\
\hline Industrial Type & Negative \& Significant & Negative \& Significant & Equal \\
\hline
\end{tabular}




\section{Summary, Conclusion and Recommendations \\ 5.1 Summary of the Research}

The aim of this study is to make a comparative analysis of sustainability reporting between the GRI standard categories of social and environmental information disclosures. The study covers all environmentally sensitive firms operating in the Nigerian economy. The independent variables applied for the research were broadly classified into five groups namely: environmental policy administrators, corporate performance, board characteristics, corporate ownership concentration and specific corporate characteristics represented by 16 elements. Analysis of the data targeted the level of sustainability disclosure, impact on sustainability disclosure, types and significance of the relationships. These were done through descriptive statistics, correlation and regression using Stata13SE analytical tool.

\subsection{Findings and Conclusions}

The result of the analysis was mixed and could be grouped into three segments:

a. Equal performance

b. Better performance by social disclosure

c. Better performance by environmental disclosure

The result show that there was equal performance between the two disclosure categories for 13 of the attributes analysed (Table 4.6). Moreover, while social disclosure had superior performances in five of the attributes observed, environmental disclosure category has superiority in only three of these attributes. In general, there was better performance by social reporting as against environmental reporting. Specifically the outcome from the analysis are:

1. Average social sustainability disclosure is higher $(50.43 \%)$ than average environmental sustainability disclosure which is $43.02 \%$. The average sustainability disclosure however, stood at $46.58 \%$. This figure is appreciable considering the fact that firms in the Nigerian economy are dominated by local firms and light industries all operating in an environment where sustainability disclosure is voluntary.

2. The total effects on social and environmental sustainability disclosures are $18.03 \%$ and $20.22 \%$ respectively giving average sustainability disclosure rate of $19.13 \%$. A result high enough to be acceptable.

3. The overall influence of the predictor variables on both social and environmental sustainability disclosures (f-statistics) are highly significant at $1 \%$ level of significance.

4. A direct relationship exists between social disclosure and NSE, profitability, firm size, financial leverage, environmental experts, board size and effective tax rate.

5. There is a positive relationship between environmental reporting and NSE, MOE, profitability, firm size, financial leverage, environmental expert, board size, firm age and effective tax rate.

6. A negative relationship exists between social reporting and DPR/ NESREA, MOE, MBV ratio, board composition, CEO duality, firm age, audit firm, corporate ownership and industry type.

7. An inverse relationship was discovered between environmental disclosure and DPR/NESREA, MBV ratio, board composition, CEO duality, audit firm, corporate ownership and industry type.

8. Significant relationship was the result between social disclosure and NSE, DPR/NESREA, firm size, MBV ratio, environmental experts, audit firm, effective tax rate, corporate ownership and industry type.

9. The relationship between environmental sustainability disclosure and NSE, profitability, firm size, CEO's duality, environmental expert, corporate ownership and industrial type were all significant.

10. Insignificant influence was the result between social disclosure and MOE, profitability, financial leverage, board composition, CEO's duality, board size and firm age.

11. Insignificant relationship was the outcome of the influence of DPR/NESREA, MOE, firm size, MBV ratio, board composition, board size, firm age, audit firm and effective tax rate on environmental sustainability disclosure. 


\subsection{Recommendations}

Based on the above discoveries, the study recommends that:

a. Results of NSE, firm size, environmental experts, corporate ownership and industry type should be maintained as they show significant results. There should however, be improvement on both corporate ownership and industrial type to make them have positive impact on both discoveries.

b. Similarly, results for DPR/NESREA, MBV ratio, audit firm and effective tax rate for social disclosure should be maintained. However, the roles of DPR/NESREA, MBV ratio and audit firm should be restructured to make them impact positively on social disclosure.

c. While environmental disclosure for profitability should be maintained and improved upon, CEO's dual role should be reassessed and improved upon so that it can impact positively on environmental sustainability disclosures.

d. The mean sustainability disclosure rates should also be maintained and improved upon for both social and environmental information reporting.

\subsection{Limitations and future Studies}

The following are some of the factors that prevents an indebt investigation into the comparison between the environmental and social aspects of sustainability information disclosure which this paper targets. Future researches may consider them in order to have a highly generalized result.

1. The scope could be extended to encompass all industries in both the formal and informal sectors of the economy or at least all listed firms.

2. Future studies could also consider other developing economies within and outside the sub-region of West Africa where Nigeria is located.

3. Make a comparative study between the three main categories of SSD (economic, environmental and social) as contained in the G4 2013 version of the GRI standard.

\section{References}

2011 SEC Code. Code of corporate governance for public companies in Nigeria (2011). Nigeria Security \& Exchange Commission.

Adams, C. A. (2004). The ethical, social, and environmental reporting-performance portrayal gap. Accounting, Auditing \& Accountability Journal. Emerald Insight. 17(5), 731-757.

Ahmad, Z., Hassan, S. \& Mohammad, J. (2003). Determinants of environmental reporting in Malaysia.International Journal of Business Studies, 11(1), 69-90.

Akbas, H. E. (2014). Company characteristics and environmental disclosures: an empirical investigation on companies listed on Borsa Istanbul 100Index.Journal of Accounting and Finance, 145-163.

Alabi, O. F., \& Ntukekpo, S. S. (2012). Oil companies and corporate social responsibility in Nigeria: an empirical assessment of chevron's community development projects in Niger delta. British Journal of Arts and Social Sciences, 4(2)2.

Alfred, C. (2013). Nigeria Agip Oil Company's corporate social responsibility in the Niger delta of Nigeria: an assessment of an unusual corporate social responsibility paradigm. Journal of Sustainable Development in Africa, 15(8).

Allen, F. (2012). Implementation of oil related environmental policies in Nigeria: government inertia and conflict in the Niger delta. Cambridge Scholars Publishing, UK.

Alrazi, B., Sulaiman, M. \& Ahmad, N. N. N. (2009). A longitudinal examination of environmental reporting practices in Malaysia. Internal Journal of Business, 11(1), 3772.https://www.researchgate.net/publication

Anderson, D. (2003). Environmental reporting and transport - the case of a public transport company. Business Strategy and the Environment, 12 386-399.

Andrikopoulos, A. \& Kriklani, N. (2013). Environmental disclosure and financial characteristics of the firm: the case of Denmark. Corporate Social Responsibility and Environmental Management 
Journal, 20, 55-64.

Aquino, M. N. (2009). An evaluation of financial and non-financial environmental disclosures of ten publicly listed mining companies in the Philippines. DLSU Business and Economics Review, 18(2), 55-64.

Asaolu, T. O., Agboola, A. A., Ayoola, T. J., \& Salamu, M. K. (2011). Sustainability in the Nigerian oil and gas sector. Environmental Management Conference Proceedings, Federal University of Agriculture Abeokuta, Nigeria.

Ayoola, T. J., \& Olasanmi, O. O. (2013). Business case for integrated reporting in Nigeria oil and gas sector. Issues in Social and Environmental Accounting, 7(1), 30-54.

Ball, A., Owen, D. L. \& Gray, R. (2000). External transparency or internal capture? The role of thirdparty statements in adding value to corporate environmental reports. Business Strategy and the Environment, 9, 1-23.

Basalamah, A. S. \& Jermias, J. (2005, January-April). Social and environmental reporting and auditing in Indonesia: maintaining organizational legitimacy? Gadjah Mada International Journal of Business, 7(1), 109-127.

Beets, S. D., \& Souther, C. C. (1999). Corporate environmental reports: The need for standards and an environmental assurance service. Accounting Horizons, 13(2), 129-145.

Bhattacharya, A. (2014). Factors associated with the social and environmental reporting of Australian companies. AABF Journal, 8(1), 25-49.

Brown, H. S., de Jong, M., \& Lessidrenska, T. (2007, May). The rise of global reporting initiative (GRI) as a case of institutional entrepreneurship. Corporate Social Responsibility Initiative Working Paper No. 36. Cambridge, MA: John F. Kennedy School of Government, Harvard University. Pp. 1-48.

Carol, A. A. and Frost, G. - CIMA (2006). Accounting for ethical, social, environmental, and economic issues: Towards an integrated approach. Research Executive Summary Series, 2(12), 1-6.

Chown, D. (2001). A review of the social, economic, and environmental impact of the forestry industry in South Africa. An M. Inst. Agrar. Research Report submitted to the School for Agriculture and Rural Development, University of Pretoria.

Clarkson, P. M., Overell, M. B., \& Chapple, L. (2011). Environmental reporting and its relation to corporate environmental performance. ABACUS - A Journal of Accounting, Finance, and Business Studies, 47(1), 27-60.

Connors, E. \& Gao, L. S. (2011). Corporate environmental performance, disclosures, and financialfinancial-financial leverage: an integrated approach. International Review of Accounting, Banking, and Finance, 3(3), 1-26.

Cormier, D., Gordon, I. M. and Magnan, M. (2004). Corporate environmental disclosure: Contrasting management's perception with reality. Journal of Business Ethics, 49, 143-165.

Cortez, M. A. A. (2011). Do markets care about social and environmental performance? Evidence from the Tokyo stock exchange. Journal of International Business Research, 10(2), 15-22.

Elijido-Ten, E. (2009). Can stakeholder theory add to our understanding of Malaysian environmental reporting attitudes? Researchgate: Malaysian Accounting Reviews, 8(2), 85-110.

Enahoro, J. A. (2009). Design and bases of environmental accounting in oil and gas and manufacturing sectors in Nigeria. A PhD Thesis submitted to Department of Accounting, College of Business and Social Sciences, Covenant University, Ota, Nigeria.

Initiative, G. R. (2013). G4 sustainability reporting guidelines. Global Reporting Initiative: Amsterdam, NY, USA, 3-94.

Kantudu, S. A. (2006). Application of accounting standards on employee retirement benefits by quoted firms in Nigeria. PhD Accounting and Finance Thesis. Zaria, Post Graduate School, Ahmadu Bello University.

NSE FactBook (2012/2013). Nigerian Stock Exchange. www.nigerianstockexchange.com

Nyor, T. (2008). Assessment of the level of accounting information disclosed in the financial statements 
of Nigerian banks. A Ph.D. Thesis presented to the Department of Economics and Management Sciences, Nigerian Defence Academy, Kaduna.

Tilt, C. A. \& Symes, C. F. (2000). Environmental disclosure by Australian mining companies: Environmental conscience or commercial reality? Feature Article. Blackwell Publication Ltd. Accounting Forum, 23(2), 137-154.

Tsafe, B. M. (2013). Stakeholders' perceptions on corporate governance constitution and their implications on board performance. Ph.D. thesis Othman Yeop Abdullah Graduate School of Business, Universiti Utara, Malaysia.

Uwuigbe, U. (2012, September). Web-based corporate environmental reporting in Nigeria: a study of listed companies. Internal Auditing and Risk Management, Annul VII, 3(2), 57-72. 
Appendix I

Correlation Matrix for Social Sustainability Disclosure

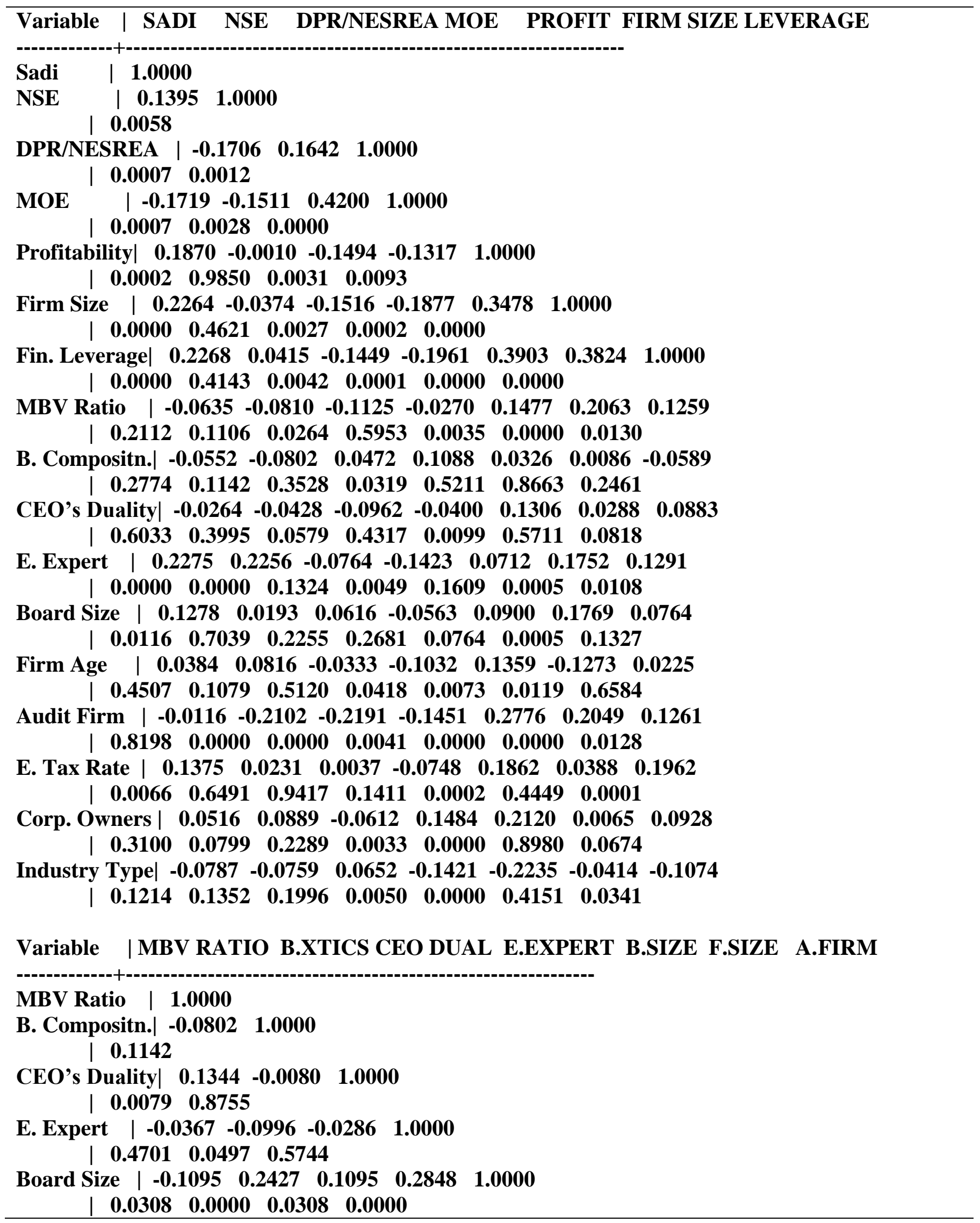




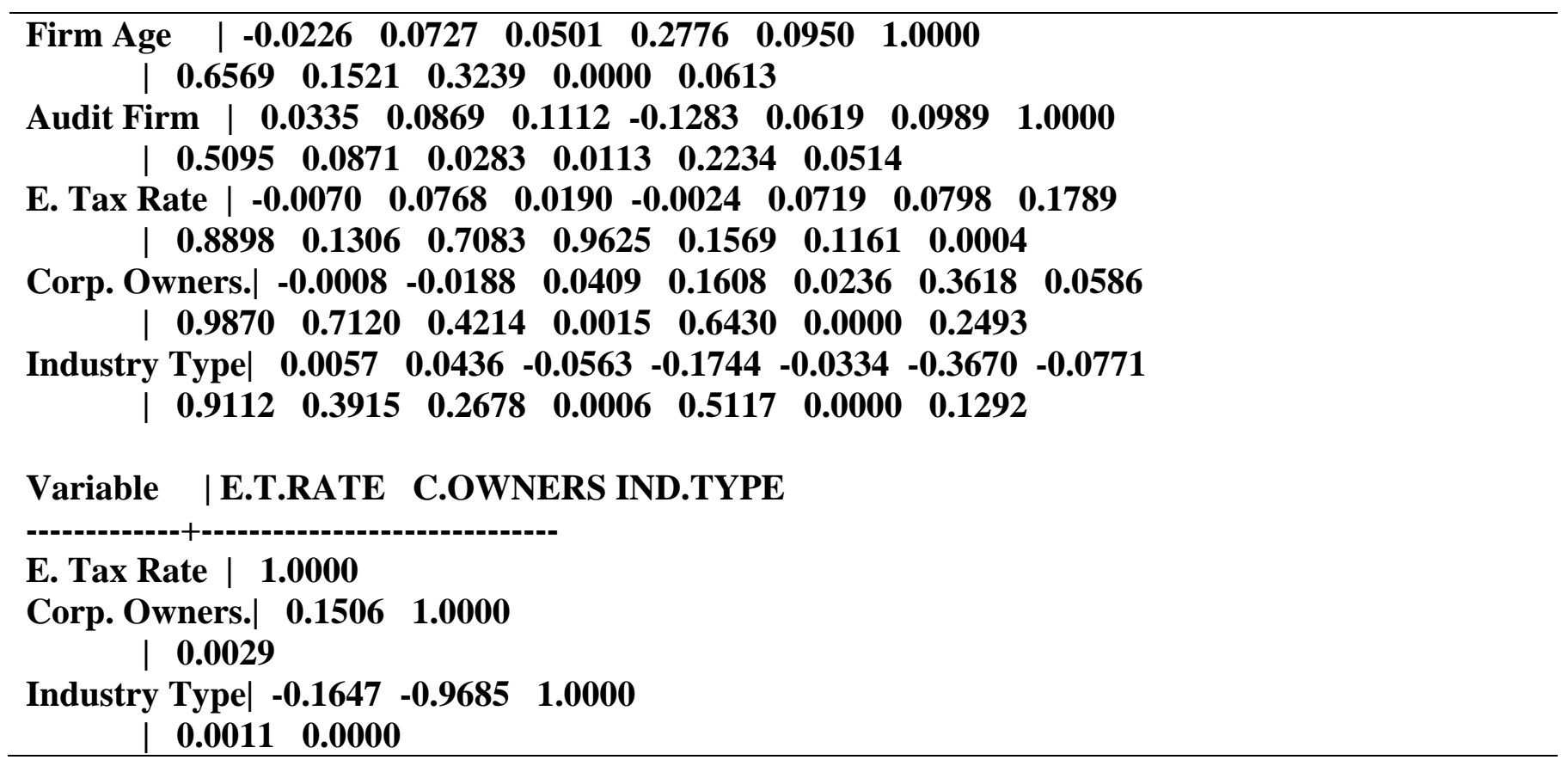




\section{Appendix II}

\section{Correlation Matrix for Environmental Sustainability Disclosure}

\begin{tabular}{|c|c|c|}
\hline Variable & $\begin{array}{lll}\text { SADI } & \text { NSE } & \text { DPR/NESREA MOE }\end{array}$ & PROFIT FIRM SIZE LEVERAGE \\
\hline SADI & 1.0000 & \\
\hline NSE & $\begin{array}{ll}0.1861 & 1.0000 \\
0002 & \end{array}$ & \\
\hline DPR/NE: & \begin{tabular}{l|lll} 
EA & -0.1366 & 0.1642 & 1.0000 \\
0070 & 0.0012 & &
\end{tabular} & \\
\hline MOE & $\begin{array}{cccc}-0.1654 & -0.1511 & 0.4200 & 1.0000 \\
0011 & 0.0028 & 0.0000 & \end{array}$ & \\
\hline
\end{tabular}

Profitability| $0.2070 \quad-0.0010 \quad-0.1494 \quad-0.1317 \quad 1.0000$ | $\begin{array}{llll}0.0000 & 0.9850 & 0.0031 & 0.0093\end{array}$

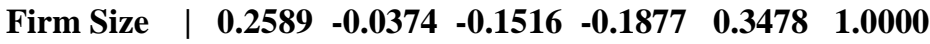
\begin{tabular}{llllll}
\hline & 0.0000 & 0.4621 & 0.0027 & 0.0002 & 0.0000
\end{tabular}

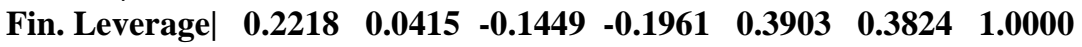

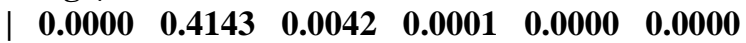

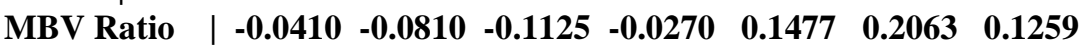

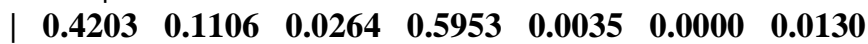

B. Compositin| $\begin{array}{rllllll}-0.0450 & -0.0802 & 0.0472 & 0.1088 & 0.0326 & 0.0086 & -0.0589\end{array}$

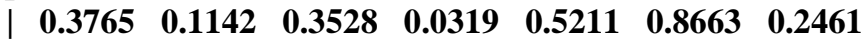

CEO Duality $\mid \begin{array}{ccccccc}-0.0619 & -0.0428 & -0.0962 & -0.0400 & 0.1306 & 0.0288 & 0.0883\end{array}$

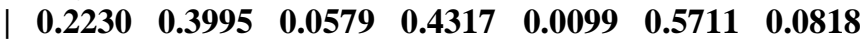

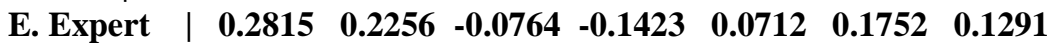

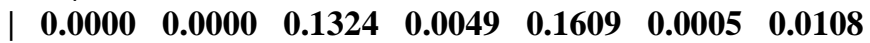

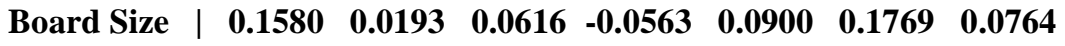

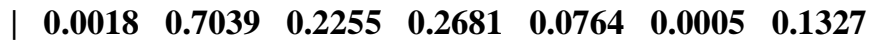

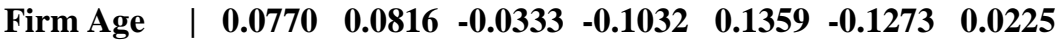

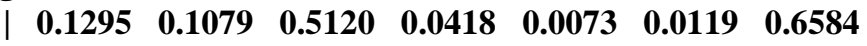

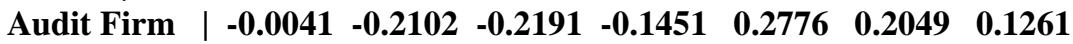

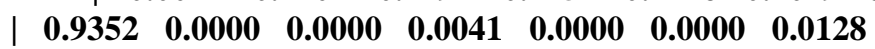

E. Tax Rate | $0.0738 \quad 0.0231 \quad 0.0037 \quad-0.0748 \quad 0.1862 \quad 0.0388 \quad 0.1962$

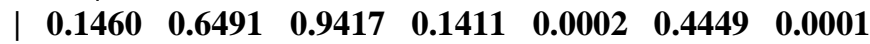

$\begin{array}{llllllll}\text { Corp. Owners.| } & 0.0979 & 0.0889 & -0.0612 & 0.1484 & 0.2120 & 0.0065 & 0.0928\end{array}$ $\begin{array}{|llllllll|}\mid & 0.0538 & 0.0799 & 0.2289 & 0.0033 & 0.0000 & 0.8980 & 0.0674\end{array}$

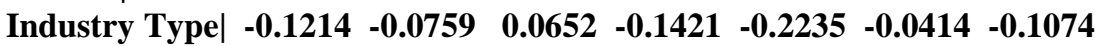
\begin{tabular}{llllllll}
\hline & 0.0166 & 0.1352 & 0.1996 & 0.0050 & 0.0000 & 0.4151 & 0.0341
\end{tabular}

Variable | MBV RATIO B.XTICS C.DUALITY E.EXPERT B.SIZE FIRM AGE AUDIT FIRM

MBV Ratio | $\mathbf{1 . 0 0 0 0}$

Board| $-\mathbf{- 0 . 0 8 0 2} \mathbf{1 . 0 0 0 0}$

| 0.1142

CEO Duality | $0.1344-0.00801 .0000$ | 0.00790 .8755

E. Expert | $-0.0367-0.0996-0.0286 \quad 1.0000$ | $0.47010 .0497 \quad 0.5744$

B. Compostion| $\begin{array}{ccccc}0.1095 & 0.2427 & 0.1095 & 0.2848 & 1.0000\end{array}$ | $\begin{array}{llll}0.0308 & 0.0000 & 0.0308 & 0.0000\end{array}$

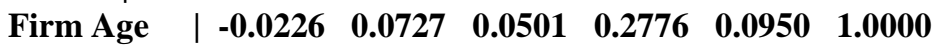
\begin{tabular}{llllll}
\hline & 0.6569 & 0.1521 & 0.3239 & 0.0000 & 0.0613
\end{tabular}

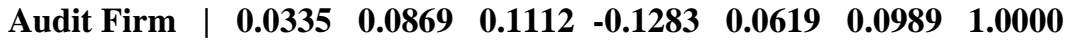

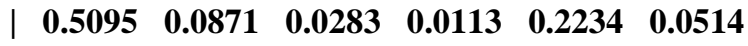

E. Tax Rate | $\begin{array}{ccccccc}-0.0070 & 0.0768 & 0.0190 & -0.0024 & 0.0719 & 0.0798 & 0.1789\end{array}$

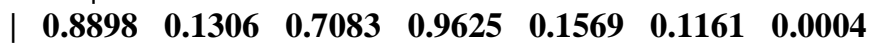

$\begin{array}{llllllll}\text { Corp. Owners.| } & -0.0008 & -0.0188 & 0.0409 & 0.1608 & 0.0236 & 0.3618 & 0.0586\end{array}$

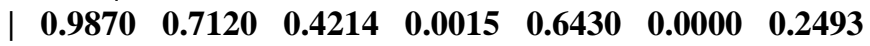

$\begin{array}{llllllll}\text { Industry Type } & 0.0057 & 0.0436 & -0.0563 & -0.1744 & -0.0334 & -0.3670 & -0.0771\end{array}$ $\begin{array}{lllllllll}0.9112 & 0.3915 & 0.2678 & 0.0006 & 0.5117 & 0.0000 & 0.1292\end{array}$ 
Variable | E.EXPERT C.OWNERS INDUS. TYPE

E. Tax Rat | 1.0000

Corp. Owners.| 0.15061 .0000 | 0.0029

Industry Type| $-\mathbf{0 . 1 6 4 7} \quad-\mathbf{0 . 9 6 8 5} \quad \mathbf{1 . 0 0 0 0}$

0.00110 .0000 


\section{Appendix III \\ Mean Value Index Computation}

This Questionnaire was prepared to serve environmental monitoring agencies with the responsibility of enforcing environmental standards and guidelines in Nigeria and targets any of the following in organizations where administered: Chief Executive Officers, or Health, Social, and Environmental Experts in the organization.

\section{AGENCY: PERIOD: \\ NSE, DPR, NESREA \& Ministry of Environment 2009-2014 \\ SECTOR COVERED: Agriculture, Construction/Real Estate, Healthcare, Industrial Goods, Natural Resources and Oil \& Gas Sectors.}

\section{Sustainability Disclosure Compliance}

The table below contain items scored 1-5 points with the key indicating the equivalent of the responses to the questions. You are required after examining your records, to tick the appropriate box based on the performance of the sector in relation to the items outlined.

\begin{tabular}{|c|c|c|c|c|c|c|c|c|}
\hline $\mathbf{S} / \mathbf{N}$ & Items & Code & \multicolumn{6}{|c|}{ Scores } \\
\hline & & & $\mathbf{0}$ & 1 & 2 & 3 & 4 & 5 \\
\hline 1. & Number of registered firms. & REF & & & & & & \\
\hline 2. & Sectors non-environmental impact. & SEI & & & & & & \\
\hline 3. & Firms environmental policies and strategies. & FPS & & & & & & \\
\hline 4. & $\begin{array}{l}\text { The employment of Environmental experts as part of } \\
\text { management team. }\end{array}$ & EMT & & & & & & \\
\hline 5. & $\begin{array}{l}\text { The strength of Environmental Standards and Guidelines } \\
\text { for the sector. }\end{array}$ & SSG & & & & & & \\
\hline 6. & Companies' disclosure of environmental information. & EIM & & & & & & \\
\hline 7. & $\begin{array}{l}\text { Compliance with GRI environmental disclosure standards } \\
\text { and guidelines. }\end{array}$ & GED & & & & & & \\
\hline 8. & $\begin{array}{l}\text { Compliance with other international environmental } \\
\text { disclosure standards and guidelines. }\end{array}$ & IED & & & & & & \\
\hline 9. & $\begin{array}{l}\text { Lack of obstacles to the enforcement of environmental } \\
\text { rules. }\end{array}$ & OER & & & & & & \\
\hline
\end{tabular}

Mean Values Index $=$ (total scores obtained/total expected (45)

Source: $\quad$ Adapted from Ahmad, Hassan \& Mohammad (2003), Sulaiman \& Mokhtar (2012) and Monteiro \& Aibar-Guzman (2010) 
